\title{
METABOLIC BALANCE INVESTIGATION OF THREE CASES OF MULTIPLE MYELOMA DURING ACTH ADMINISTRATION; EXCHANGES OF CALCIUM, PHOSPHORUS, NITROGEN AND ELECTROLYTES ${ }^{1}$
}

\author{
By WILLIAM S. ADAMS, EARL D. MASON, AND SAMUEL H. BASSETT
}

(From the Veterans Administration Center, Los Angeles, Calif., and the Department of Medicine, School of Medicine, University of California Medical Center, Los Angeles, Calif.)

(Submitted for publication February 17, 1953; accepted October 8, 1953)

\section{INTRODUCTION}

In the course of some preliminary observations on the effect of ACTH in multiple myeloma we were intrigued by evidence of substantial decrease in the concentration of serum protein and diminution of Bence-Jones proteinuria (1). As in other forms of malignancy, response to steroid therapy has proven somewhat varied in the hands of different investigators. Pearson, Eliel, and Talbott (2) mentioned the inefficacy of adrenocorticotropin in plasma cell myeloma. Engle and Barr (3) treated three patients with the same substance and noted little clinical improvement. They found no change in the electrophoretic pattern or in the concentration of plasma protein. In other instances, the results have been similar to those of the authors and include reduction in concentration of serum protein as described by Bethell (3) and other investigators (4); decreased excretion of Bence-Jones protein (3) ; disappearance of hypercalcemia $(3,4)$; and clinical improvement (such as loss of bone pain [3], better appetite with gain in weight $[3,4]$, and increased hematocrit). Our own experience also indicates that adrenocorticotropin diminishes rather than aggravates the rate of skeletal decalcification. This impression has been gained through careful observation of three patients who were hospitalized for metabolic study. That it may also lead occasionally to a prolonged remission was suggested by the clinical response of one of our three subjects treated with this hormone. Although other workers have investigated nitrogen and mineral exchanges in myeloma (5-

1 Supported in part by a grant-in-aid from the American Cancer Society upon recommendation of the Committee on Growth of the National Research Council, and by the Cancer Research Coordinating Committee of the University of California.
11), their findings do not appear pertinent to the present discussion.

\section{PROCEDURE AND METHODS}

The patients were admitted to the Metabolism Ward where they were under continuous observation. The urine was analyzed daily for sodium, potassium, phosphorus, chloride, and nitrogen; aliquots of the 24-hour collections of urine were saved and pooled in periods of five days, and the analyses repeated on the pooled samples. This served as an added check on the accuracy of the daily work. Stools were separated at intervals of five days with the use of carmine markers and analyzed for the same constituents as in the case of urine. Sample diets, duplicating the menus of the patients, were prepared at intervals of ten days, homogenized, sampled, and analyzed to determine intake. Emeses and dietary rejects were treated in the same manner as sample diets, analyzed separately, and appropriate corrections of intake were made. Blood was collected in the postabsorptive state from an arm vein with the least possible stasis, and after prompt separation of the serum, determinations were made of total serum protein, albumin, globulin, sodium, chloride, potassium, calcium, and phosphorus. The analytical methods used were as follows: Aliquots of diet, urine, and emesis were ashed in a muffle furnace at a temperature not exceeding $450^{\circ} \mathrm{C}$. Sodium and potassium determinations were performed directly on diluted specimens of urine and (blood) serum, with the use of the Beckman flame photometer. With the exception of nitrogen and chloride, the other substances were determined from the ashed filtrates. Urinary, fecal, and dietary calcium were determined by the gravimetric method of Washburn and Shear (12), serum calcium by the method of Van Slyke and Sendroy (13), phosphorus by the gravimetric method of Washburn and Shear (12), and a modification of the colorimetric method of Fiske and Subbarow (14), nitrogen by the Hiller, Plazin, and Van Slyke modifications of the Kjeldahl procedure (15), chlorides by modification of the Volhard method (16-18), plasma proteins by a modification of the Howe sodium sulfate method (19) as described by Majoor (20), and urinary protein by the method of Hiller, Greif, and Beckman (21), serum and urine uric acid by modification of the methods of Kalckar (22) and Praetorius (23). 


\section{CLINICAL MATERIAL}

\section{Case summaries}

\section{Patient 1 (J. D.) (See Figures 1-4 and Tables I-III.)}

J. D. was a white male aged 62 who was found to have multiple myeloma in 1946, while under treatment for lobar pneumonia. Although he was moderately anemic and exhibited hyperproteinemia and infiltration of the bone marrow with plasma cells, roentgenologic evidence of skeletal decalcification was not yet apparent. During the subsequent two years he had repeated respiratory infections and was readmitted to the hospital in June, 1948 with right lower lobe pneumonia. At this time the erythrocyte count was 3.8 million per cu. mm., the red cells showed increased rouleaux formation, the hemoglobin was $11.2 \mathrm{Gm}$. per $100 \mathrm{ml}$. whole blood, the white blood cells were 17,000 per cu. mm. with a shift to the left in the differential formula. Bence-Jones protein was present in the urine and sternal marrow was heavily infiltrated with plasma cells. The skull revealed discrete radiolucent areas. The serum proteins were $8.6 \mathrm{Gm}$. per cent with $3.2 \mathrm{Gm}$. per cent albumin and $5.4 \mathrm{Gm}$. per cent globulin. (The main globulin component could be precipitated with 18.5 per cent sodium sulfate.) Urethane in the amount of $135 \mathrm{Gm}$. given over a period of 45 days failed to produce clinical improvement or any alterations in existing abnormalities detectible in the laboratory.

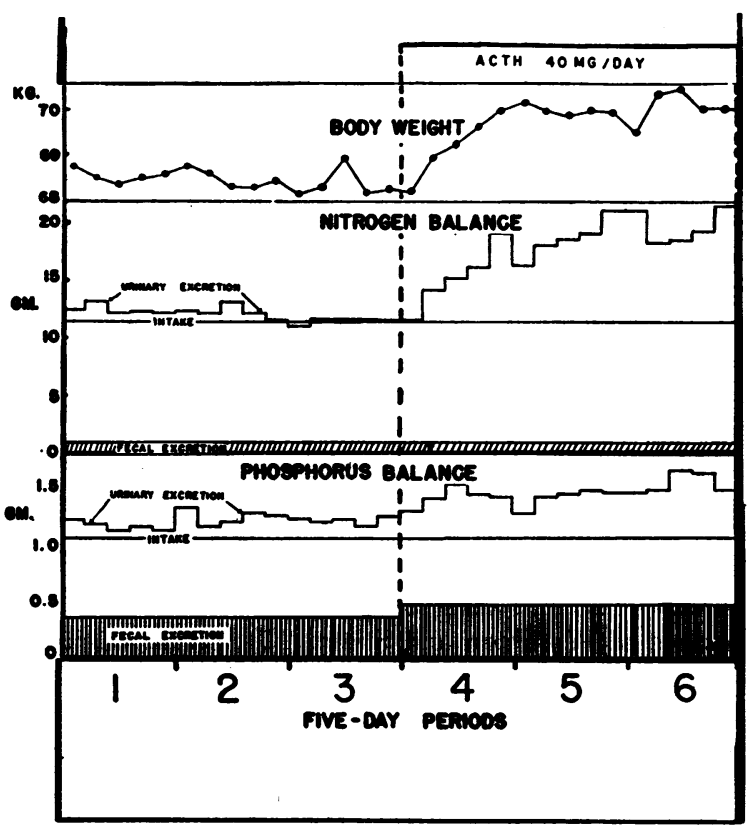

Fig. 1. Patient J. D. Effect of ACTH on Nitrogrn and Phosphorus Balance and Body Weight

Positive balances are indicated by clear areas between the intake line and the sum of urine and fecal excretion. An extension of the line labeled "urinary excretion" above the line labeled "intake" denotes a negative balance.
A year after urethane therapy he was admitted to the metabolic ward for a study of the effect of adrenocorticotropin, the results of which are indicated in tables and charts. After 15 days of treatment, he suddenly became febrile, and metabolic studies had to be discontinued. Signs of meningeal irritation developed and within a few days he became semistuporous. His condition became progressively worse, and he lapsed into complete coma and died in two weeks.

Cultures of the blood and spinal fluid remained sterile. Autopsy revealed a purulent ependymitis, the cause of which was not ascertained. Examination of the bone marrow at autopsy confirmed the diagnosis of multiple myeloma.

\section{Patient 2 (J.M.) (See Figures 5-8 and Tables II-V.)}

J. M., a white male of 56 years was admitted to the hospital for the first time in 1947 with severe back pain which had its inception while he was lifting a heavy object. There was a pathological fracture of the tenth dorsal vertebra and multiple radiolucent areas scattered throughout the skeleton. The diagnosis of multiple myeloma was substantiated by biopsy of the bone marrow. He received therapy with urethane $(120 \mathrm{Gm}$. in 45 days) but failed to improve either from a clinical or laboratory standpoint. During a subsequent readmission six months later, little new was noted on physical examination, except for spasm of the erector spinae muscle in the lower thoracic and upper lumbar regions. $\mathrm{X}$-rays at this time indicated compression fractures of D-8, D-10, and L-1, the

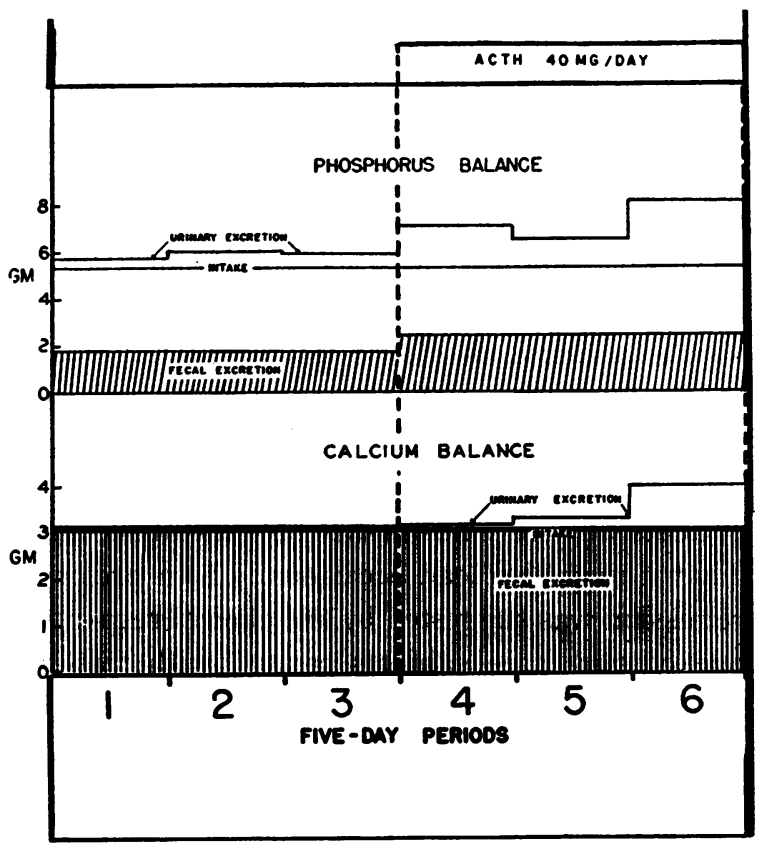

Fig. 2. Patient J. D. Effect of aCth on Calcium and Phosphorus Balances

For legend see Figure 1. 


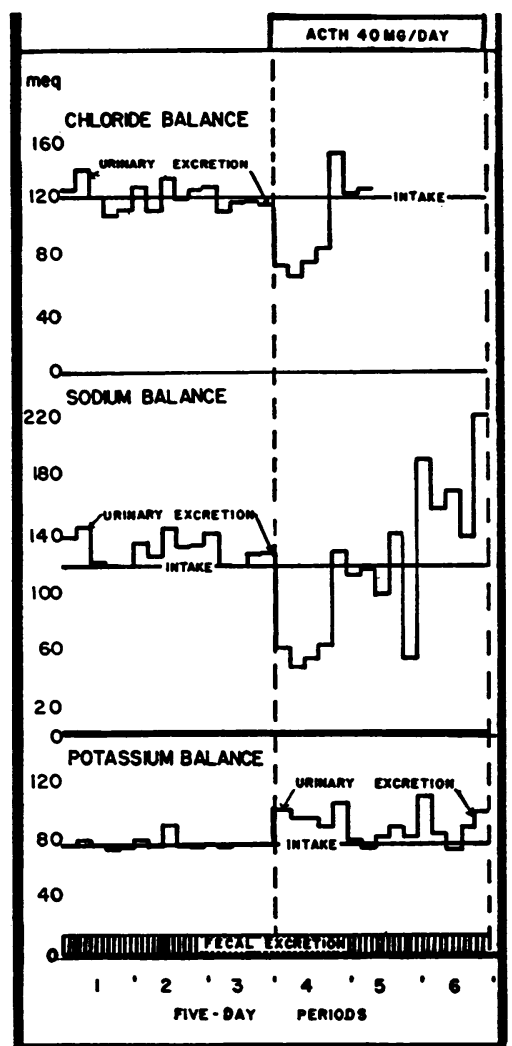

Fig. 3. Patient J. D. Efrect of ACTH on Sodium Chloride and Potassium Balances

For legend see Figure 1.

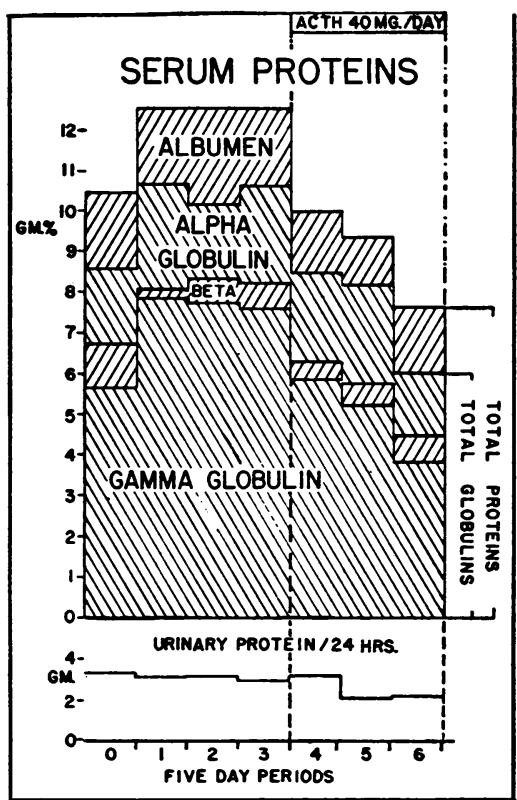

Fig. 4. Patient J. D. Effect of ACth on Serum and Urinary Protein

presence of decalcified areas as mentioned previously, and considerable demineralization of all the bones. The total serum proteins were $7.1 \mathrm{Gm}$. per cent, albumin $3 \mathrm{Gm}$. per cent, globulin $4.1 \mathrm{Gm}$. per cent with the major abnormality in the alpha globulin component (a somewhat unusual finding but one that has been observed previously $[24,25])$. Bence-Jones protein was present in the urine in considerable quantity, and the sternal marrow contained 42 per cent plasma cells. He was admitted to the

TABLE I

Nitrogen, calcium, phosphorus, and electrolyte balances*

\begin{tabular}{|c|c|c|c|c|c|c|c|c|}
\hline \multirow{3}{*}{$\begin{array}{c}\text { Period } \\
5 \text { days ea. }\end{array}$} & \multirow{3}{*}{$\begin{array}{l}\text { Therapy } \\
\text { (daily) }\end{array}$} & & J. D. & Age 62 & Male & & & \multirow{3}{*}{$\begin{array}{c}\text { Weight } \\
K_{\mathbf{B} .}\end{array}$} \\
\hline & & $\mathrm{Ca}$ & $\mathbf{P}$ & $\mathbf{N}$ & $\mathrm{Na}$ & $\mathbf{K}$ & $\mathrm{Cl}$ & \\
\hline & & \multicolumn{3}{|c|}{$G m$. } & \multicolumn{3}{|c|}{$m E q}$. & \\
\hline $\begin{array}{l}\text { I } \\
\text { II } \\
\text { III } \\
\text { IV } \\
\text { V } \\
\text { VI }\end{array}$ & $\begin{array}{c}\text { Control } \\
\text { Control } \\
\text { Control } \\
40 \mathrm{mg} . \text { ACTH } \\
40 \mathrm{mg} . \text { ACTH } \\
40 \mathrm{mg} \text {. ACTH }\end{array}$ & $\begin{array}{l}-0.176 \\
-0.191 \\
-0.176 \\
-0.251 \\
-0.500 \\
-0.921\end{array}$ & $\begin{array}{l}-0.544 \\
-0.916 \\
-0.781 \\
-1.796 \\
-1.780 \\
-2.422\end{array}$ & $\begin{array}{l}-4.81 \\
=3.53 \\
=0.42 \\
=18.89 \\
-35.66 \\
-41.27\end{array}$ & $\begin{array}{l}-54.60 \\
=\quad 7.30 \\
-48.10 \\
+232.40 \\
-\quad 5.40 \\
-225.70\end{array}$ & $\begin{array}{l} \pm \quad 0.10 \\
\pm \quad 14.60 \\
=\quad 0.80 \\
=102.20 \\
=\quad 37.79 \\
-57.09\end{array}$ & $\begin{array}{l}-\quad 0.41 \\
=10.20 \\
+\quad 20.30 \\
+155.60 \\
+\quad 38.57 \\
-233.35\end{array}$ & $\begin{array}{l}68.52 \\
68.53 \\
68.38 \\
69.97 \\
69.89 \\
70.00\end{array}$ \\
\hline
\end{tabular}

* In computation of these balances average values for dietary intake and fecal excretion have been employed (actual analyses of both diet and stool having been carried out every five-day period). The diet was calculated to contain $72 \mathrm{Gm}$. of protein, $123 \mathrm{Gm}$. of fat, and $174 \mathrm{Gm}$. of carbohydrate, and 2093 calories per day. The average values per five-day period were as follows:

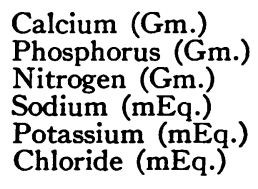

$\begin{array}{cc}\text { Diet } & \text { Fecal excretion } \\ 3.119 & 3.224 \\ 5.30 & 1.556 \\ 57.65 & 5.08 \\ 580.0 & 7.83 \\ 371.0 & 60.45 \\ 606.0 & 6.05\end{array}$


TABLE II

Urinary proteins

\begin{tabular}{|c|c|c|c|c|c|c|}
\hline \multirow[b]{2}{*}{ Period } & \multicolumn{2}{|c|}{ Case J. D. } & \multicolumn{2}{|c|}{ Case J. M. } & \multicolumn{2}{|c|}{ Case S. M. } \\
\hline & $\begin{array}{c}\text { Therapy } \\
\text { daily } \\
\text { ACTH } \\
\text { (mg.) }\end{array}$ & $\underset{\text { urinary* }}{\text { Total }}$ & $\begin{array}{c}\text { Therapy } \\
\text { daily } \\
\text { ACTH } \\
\text { (mg.) }\end{array}$ & $\underset{\substack{\text { Totalinary* } \\
\text { protein }}}{\text { Tot }}$ & $\begin{array}{c}\text { Therapy } \\
\text { daily } \\
\text { ACTH } \\
\text { (mg.) }\end{array}$ & $\underset{\text { prinary }}{\text { Total }}$ \\
\hline $\begin{array}{r}\text { II } \\
\text { III } \\
\text { IV } \\
\text { VI } \\
\text { VII } \\
\text { VIII } \\
\text { IX } \\
\underset{X}{X I} \\
\text { XII } \\
\text { XIII } \\
\text { XIV } \\
\text { XV } \\
\text { XVI } \\
\text { XVII } \\
\text { XVIII }\end{array}$ & $\begin{array}{l}- \\
\overline{-} \\
40 \\
40 \\
40\end{array}$ & $\begin{array}{l}15.4 \\
16.0 \\
15.0 \\
15.8 \\
11.0 \\
10.8\end{array}$ & $\begin{array}{l}- \\
- \\
\overline{40} \\
40 \\
40 \\
80 \\
80 \\
80 \\
40 \\
40 \\
40 \\
40 \\
-\end{array}$ & $\begin{array}{l}87.6 \\
86.5 \\
91.2 \\
94.6 \\
82.8 \\
66.0 \\
37.2 \\
26.9 \\
22.2 \\
22.3 \\
27.1 \\
28.6 \\
26.6 \\
27.2 \\
31.2\end{array}$ & $\begin{array}{l}- \\
\overline{-} \\
100 \\
100 \\
200 \\
200 \\
200 \\
100 \\
100 \\
100 \\
100 \\
100 \\
100 \\
100 \\
100 \\
- \\
-\end{array}$ & $\begin{array}{r}44.7 \\
45.6 \\
48.4 \\
48.8 \\
40.2 \\
28.6 \\
11.5 \\
7.9 \\
3.8 \\
4.6 \\
3.6 \\
3.7 \\
3.3 \\
3.3 \\
4.6 \\
3.4 \\
4.3 \\
6.1\end{array}$ \\
\hline
\end{tabular}

* Grams protein per five-day period.

metabolic unit for studies which were continued for 75 days. During 50 days of this time he received a course of ACTH which resulted in marked subjective improvement, although in no sense did it eradicate signs of the disease. Approximately one year later he developed a sudden paraplegia, "cord" bladder, and fecal incontinence. Cortisone therapy was tried but he became progressively worse and died in August, 1951. The diagnosis of multiple myeloma was confirmed at autopsy.
Patient 3 (S.M.) (See Figures 8-13 and Tables II, III, V-VII.)

S. M., a white male of 58 years, entered the hospital in March 1949 with a six-month history of pain in the back and shoulders, weakness of and loss of sensation in the lower extremities. He had been confined to bed for the month prior to admission because of inability to move his legs. On examination, he was found to have a spastic paraplegia, diminution of sense of pain and touch over

TABLE III

Urinary calcium

\begin{tabular}{|c|c|c|c|c|c|c|}
\hline \multirow[b]{2}{*}{ Period } & \multicolumn{2}{|c|}{ Case J. D. } & \multicolumn{2}{|c|}{ Case J. M. } & \multicolumn{2}{|c|}{ Case S. M. } \\
\hline & $\begin{array}{c}\text { Therapy } \\
\text { daily } \\
\text { ACTH } \\
\text { (mg.) }\end{array}$ & $\underset{\mathrm{Ca}^{*}}{\text { Urinary }}$ & $\begin{array}{l}\text { Therapy } \\
\text { daily } \\
\text { ACTH } \\
\text { (mg.) }\end{array}$ & $\underset{\mathrm{Ca}^{*}}{\text { Urinary }}$ & $\begin{array}{c}\text { Therapy } \\
\text { daily } \\
\text { ACTH } \\
\text { (mg.) }\end{array}$ & $\underset{\mathrm{Ca}^{*}}{\text { Urinary }}$ \\
\hline $\begin{array}{r}\text { II } \\
\text { II } \\
\text { III } \\
\text { IV } \\
\text { V } \\
\text { VI } \\
\text { VII } \\
\text { VIII } \\
\text { IX } \\
\underset{X}{X I} \\
\text { XII } \\
\text { XIII } \\
\text { XIV } \\
\text { XV } \\
\text { XVI } \\
\text { XVII } \\
\text { XVIII }\end{array}$ & $\begin{array}{l}- \\
\overline{-} \\
40 \\
40 \\
40\end{array}$ & $\begin{array}{l}0.051 \\
0.066 \\
0.051 \\
0.126 \\
0.375 \\
0.796\end{array}$ & $\begin{array}{l}- \\
- \\
40 \\
40 \\
40 \\
80 \\
80 \\
80 \\
40 \\
40 \\
40 \\
40 \\
-\end{array}$ & $\begin{array}{l}1.390 \\
1.523 \\
1.466 \\
1.244 \\
0.743 \\
0.646 \\
0.591 \\
0.790 \\
1.021 \\
1.088 \\
1.033 \\
1.029 \\
1.105 \\
0.990 \\
0.819\end{array}$ & $\begin{array}{l}\overline{-} \\
\overline{100} \\
100 \\
200 \\
200 \\
200 \\
100 \\
100 \\
100 \\
100 \\
100 \\
100 \\
100 \\
100 \\
- \\
-\end{array}$ & $\begin{array}{l}0.956 \\
1.116 \\
1.273 \\
1.294 \\
1.216 \\
1.235 \\
0.994 \\
0.987 \\
0.672 \\
0.858 \\
1.093 \\
1.098 \\
0.691 \\
0.801 \\
1.051 \\
0.956 \\
0.522 \\
0.527\end{array}$ \\
\hline
\end{tabular}

* Grams calcium per five-day period. 


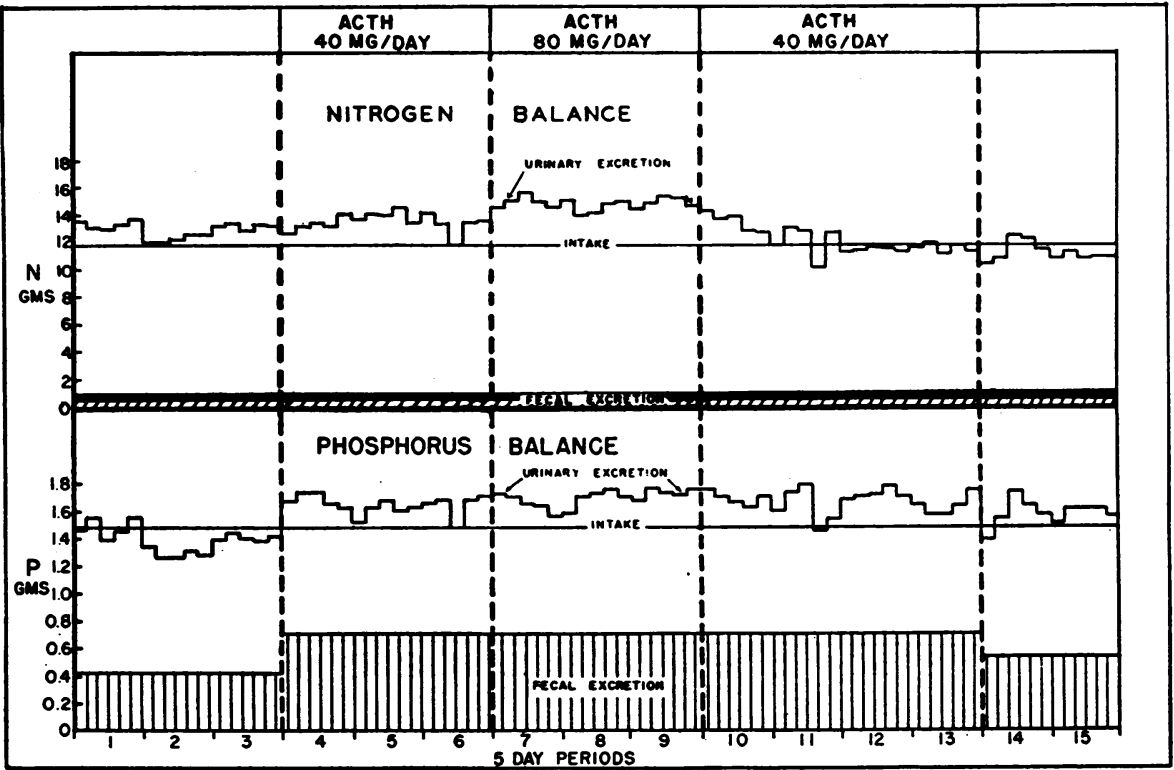

Fig. 5. Patient J. M. Effect of ACth on Nitrogen and Phosphorus Balances For legend see Figure 1.

the legs, and multiple osteolytic lesions which involved the skull, ribs, vertebrae, pelvis, and proximal portions of the femora. There was an expansile tumor of the inferior portion of the right scapula. The urine contained Bence-Jones protein; the serum proteins showed a slight increase in the alpha globulin fraction but were not otherwise remarkable. Smears of the sternal marrow revealed
22 per cent plasma cells, some of which were multinucleated. Although the diagnosis of multiple myeloma appeared to be well substantiated, it was decided to attempt to relieve the paraplegia by laminectomy. The operation was performed in April, 1949, and an infiltrating mass, which proved to be a plasmacytoma, was removed from the spinal cord at the level of D-1. Use of graded

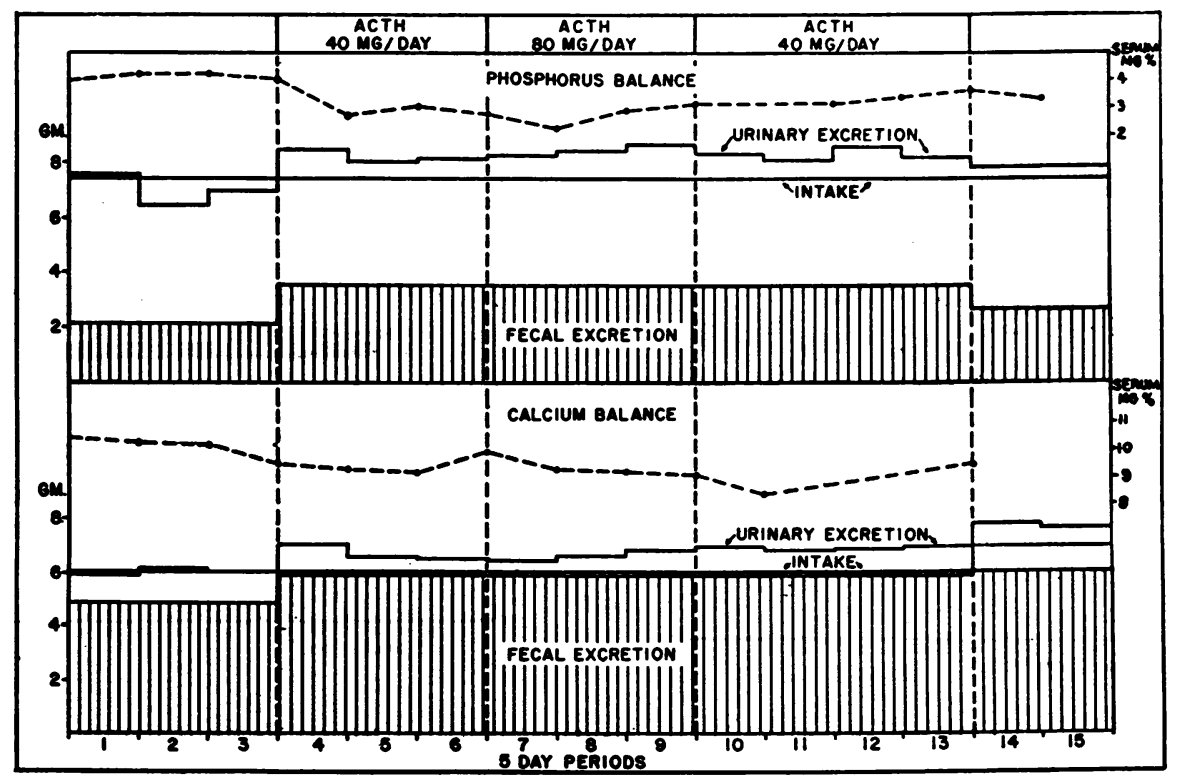

Fig. 6. Pattent J. M. Effect of aCth on Calcium and Phosphorus Balances For legend see Figure 1. 


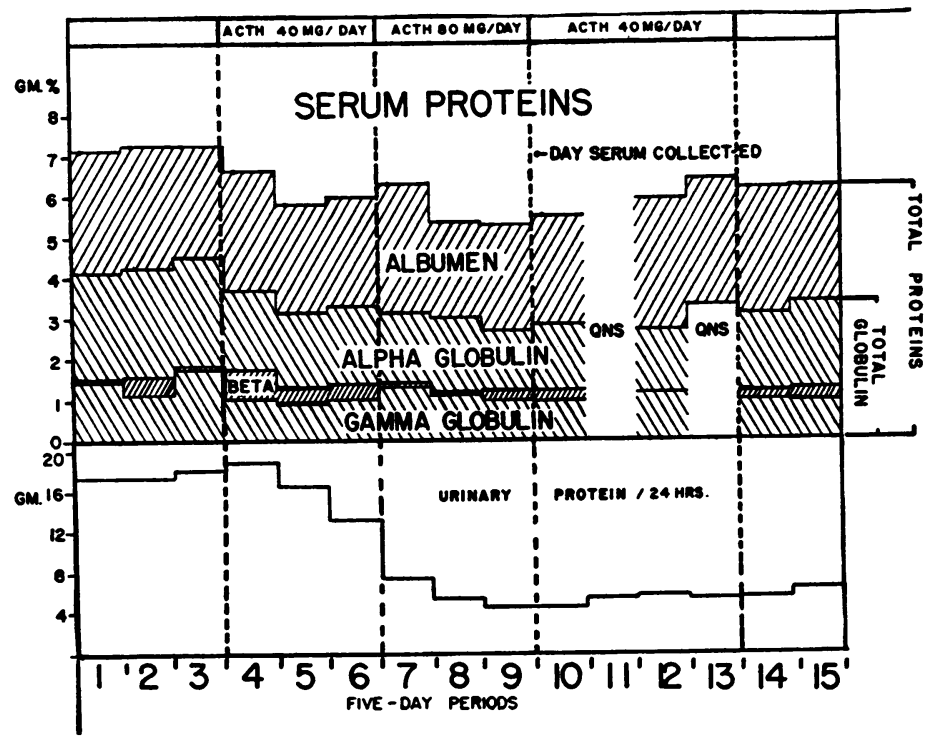

Fig. 7. Patient J. M. Effect of ACth on Serum and Urinary Protein

exercises and physiotherapy led to a gradual recovery of function in the lower extremities which was nearly complete a year later. Repeated episodes of severe rib and back pain continued, however, and in January, 1951, he entered the Metabolic Unit for treatment with adrenocorticotropin. The results of studies conducted at this time are illustrated in figures and tables. A remission in the course of the disease followed the administration of the hormone and now, two years later, he is active and subjectively well. However, bone marrow and roentgen evidence of myeloma persists.

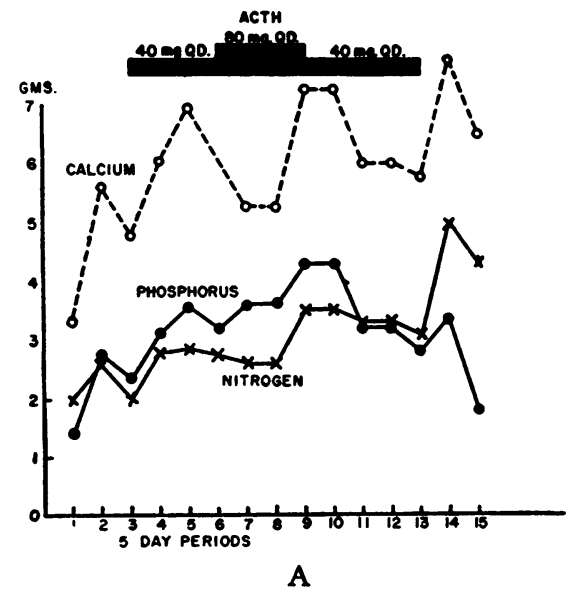

\section{METABOLIC STUDIES}

The alterations in the exchanges of nitrogen, calcium, phosphorus, and electrolytes associated with the administration of $\mathrm{ACTH}^{2}$ to these three patients, were in many respects similar to the effects observed in normal subjects and in various other

2 The ACTH used in this study was supplied by Armour \& Company. All dosages are expressed in terms of Armour's standard LA-1A.

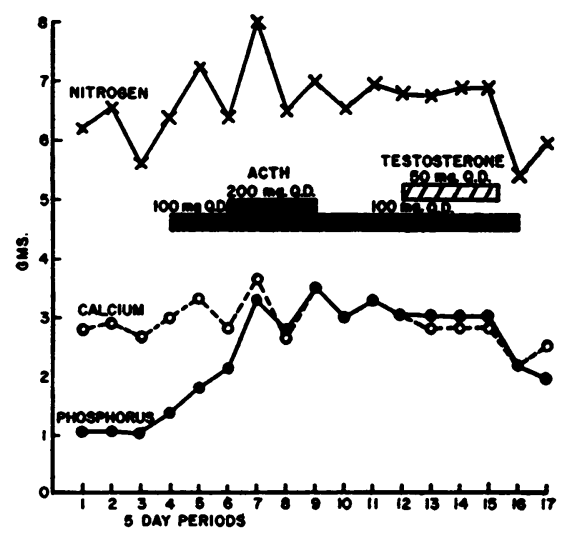

B

Fig. 8. A. Patient J. M. Effect of ACth on Fecal loss of Nitrogen, Calcium, and PHOSPHORUS

B. Patient S. M. Effect of ACth on Fecal loss of Nitrogen, Calcium, and Phosphorus 
TABLE IV

Nitrogen, calcium, and phosphorus balances*

\begin{tabular}{|c|c|c|c|c|c|c|}
\hline \multirow{3}{*}{$\begin{array}{c}\text { Period } \\
5 \text { days ea. }\end{array}$} & \multicolumn{5}{|c|}{ J. M. Age 56 Male } & \multirow{3}{*}{$\begin{array}{c}\text { Weight } \\
K_{\boldsymbol{g}}\end{array}$} \\
\hline & \multirow{2}{*}{$\begin{array}{c}\text { Therapy } \\
\text { (daily) }\end{array}$} & $\mathbf{C a}$ & $\begin{array}{c}\mathbf{P} \\
\text { Theoretical }\end{array}$ & $\begin{array}{c}\mathbf{P} \\
\text { Actual }\end{array}$ & $\mathbf{N}$ & \\
\hline & & \multicolumn{4}{|c|}{ Gm. } & \\
\hline 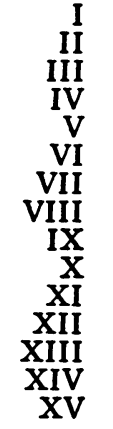 & $\begin{array}{c}\text { Control } \\
\text { Control } \\
\text { Control } \\
40 \mathrm{mg} . \text { ACTH } \\
40 \mathrm{mg} . \text { ACTH } \\
40 \mathrm{mg} \text {. ACTH } \\
80 \mathrm{mg} . \text { ACTH } \\
80 \mathrm{mg} \text {. ACTH } \\
80 \mathrm{mg} \text {. ACTH } \\
40 \mathrm{mg} . \text { ACTH } \\
40 \mathrm{mg} . \text { ACTH } \\
40 \mathrm{mg} . \text { ACTH } \\
40 \mathrm{mg} . \text { ACTH } \\
\text { Control } \\
\text { Control }\end{array}$ & $\begin{array}{l}-1.094 \\
-1.227 \\
-1.170 \\
-0.918 \\
-0.447 \\
-0.350 \\
-0.295 \\
-0.494 \\
-0.725 \\
-0.792 \\
-0.737 \\
-0.733 \\
-0.809 \\
-0.694 \\
-0.523\end{array}$ & $\begin{array}{l}-1.01 \\
-0.71 \\
-1.01 \\
-0.93 \\
-0.93 \\
-0.67 \\
-1.23 \\
-1.20 \\
-1.39 \\
-0.93 \\
-0.42 \\
-0.20 \\
-0.25 \\
-0.20 \\
+0.08\end{array}$ & $\begin{array}{l}-1.036 \\
-0.063 \\
-0.658 \\
-0.719 \\
-0.240 \\
-0.568 \\
-0.483 \\
-0.655 \\
-0.833 \\
-0.634 \\
-0.329 \\
-0.779 \\
-0.378 \\
-0.981 \\
-0.987\end{array}$ & $\begin{array}{l}-7.68 \\
=2.45 \\
=7.03 \\
-7.65 \\
-10.79 \\
=7.47 \\
-15.90 \\
-14.12 \\
-15.71 \\
-8.49 \\
=1.43 \\
+1.88 \\
+1.66 \\
+1.64 \\
+4.57\end{array}$ & $\begin{array}{l}64.84 \\
64.47 \\
64.38 \\
65.18 \\
65.05 \\
65.45 \\
66.06 \\
65.94 \\
65.19 \\
64.31 \\
63.25 \\
63.32 \\
63.85 \\
62.03\end{array}$ \\
\hline
\end{tabular}

* In computation of these balances average values for dietary intake and fecal excretion have been employed (actual analyses of both diet and stool having been carried out every five-day period). The diet was calculated to contain $68.8 \mathrm{Gm}$. of protein, $119.1 \mathrm{Gm}$. of fat, $210.1 \mathrm{Gm}$. of carbohydrate, and 1919 calories per day. The average values per five-day period were as follows:

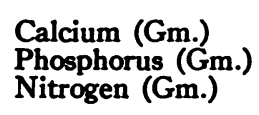

diseases $(4,26)$. There were, however, certain unique features, such as marked changes in the concentration of plasma proteins and in the amount of protein excreted in the urine $(1,3,4)$. Since the reactions of each individual differed substantially, the data for each will be described separately.

$\begin{array}{cc}\text { Diet } & \text { Fecal excretion } \\ 5.996 & 5.70 \\ 7.403 & 3.13 \\ 59.1 & 3.10\end{array}$

Patient J. D.

A. Nitrogen balance: The weight of the patient remained nearly constant $(68.5$ to $68.4 \mathrm{Kg}$.) during three control periods on a diet of $72 \mathrm{Gm}$. protein and 2093 calories per day. Small amounts of nitrogen were lost for the first ten days followed

TABLE $V$

Nitrogen to phosphorus ratios

\begin{tabular}{|c|c|c|c|c|c|c|}
\hline \multirow[b]{2}{*}{ Period } & \multicolumn{3}{|c|}{ Case J. M. } & \multicolumn{3}{|c|}{ Case S. M. } \\
\hline & $\begin{array}{l}\text { Actual P- } \\
\text { P with Ca }\end{array}$ & $\mathbf{N}$ & N/P & $\begin{array}{l}\text { Actual P- } \\
\text { P with Ca }\end{array}$ & $\mathbf{N}$ & N/P \\
\hline $\begin{array}{r}\text { II } \\
\text { III } \\
I I V \\
\text { V } \\
\text { VI } \\
\text { VII } \\
\text { VIII } \\
\text { IX } \\
\text { XI } \\
\text { XI } \\
\text { XII } \\
\text { XIII } \\
\text { XIV } \\
\text { XV } \\
\text { XVI } \\
\text { XVII } \\
\text { XVIII }\end{array}$ & $\begin{array}{c}-0.546 \\
-0.080 \\
-0.128 \\
-0.309 \\
-0.040 \\
-0.408 \\
-0.353 \\
-0.415 \\
-0.513 \\
-0.284 \\
0 \\
-0.449 \\
-0.018 \\
-0.671 \\
-0.757 \\
0 \\
0 \\
0\end{array}$ & $\begin{array}{l}-7.68 \\
=2.45 \\
=7.03 \\
=7.65 \\
=10.79 \\
=7.47 \\
=15.90 \\
=14.12 \\
=15.71 \\
=8.49 \\
=1.43 \\
+1.88 \\
+1.66 \\
+1.64 \\
+4.57 \\
= \\
=\end{array}$ & $\begin{array}{l}14.07 \\
30.63 \\
54.92 \\
24.76 \\
26.97 \\
18.31 \\
45.04 \\
34.02 \\
30.62 \\
29.89 \\
= \\
= \\
= \\
= \\
=\end{array}$ & $\begin{array}{c}-0.149 \\
-0.217 \\
-0.256 \\
-1.045 \\
-1.048 \\
-2.617 \\
-2.540 \\
-1.880 \\
-0.825 \\
-1.028 \\
-1.215 \\
0 \\
0 \\
0 \\
0 \\
-1.425 \\
-0.088 \\
-1.732\end{array}$ & $\begin{array}{l}-0.04 \\
=1.52 \\
=0.48 \\
+2.36 \\
\pm 0.60 \\
-20.71 \\
-32.97 \\
-35.56 \\
=30.45 \\
-25.59 \\
-31.26 \\
-15.38 \\
-6.99 \\
+0.33 \\
+1.49 \\
-18.35 \\
-16.54 \\
-13.05\end{array}$ & $\begin{array}{r}0.27 \\
7.01 \\
1.88 \\
\overline{0.57} \\
7.91 \\
12.98 \\
18.91 \\
36.90 \\
24.90 \\
25.72 \\
= \\
= \\
12.88 \\
18.79 \\
7.53\end{array}$ \\
\hline Average & & & 30.9 & & & 13.56 \\
\hline
\end{tabular}




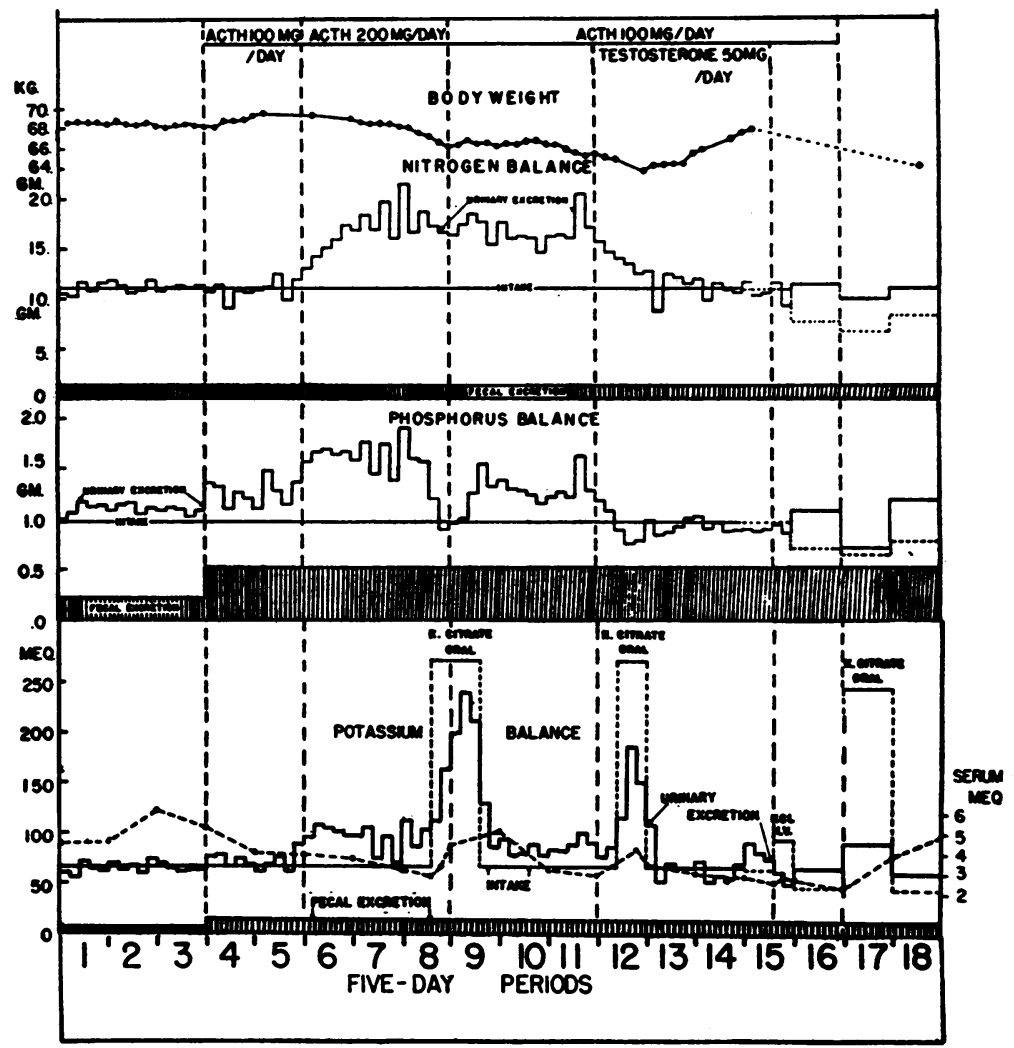

Fig. 9. Patient S. M. Effect of ACTh on Nitrogen, Phosphorus, Potassium, Balances and Body Weight

For legend see Figure 1.

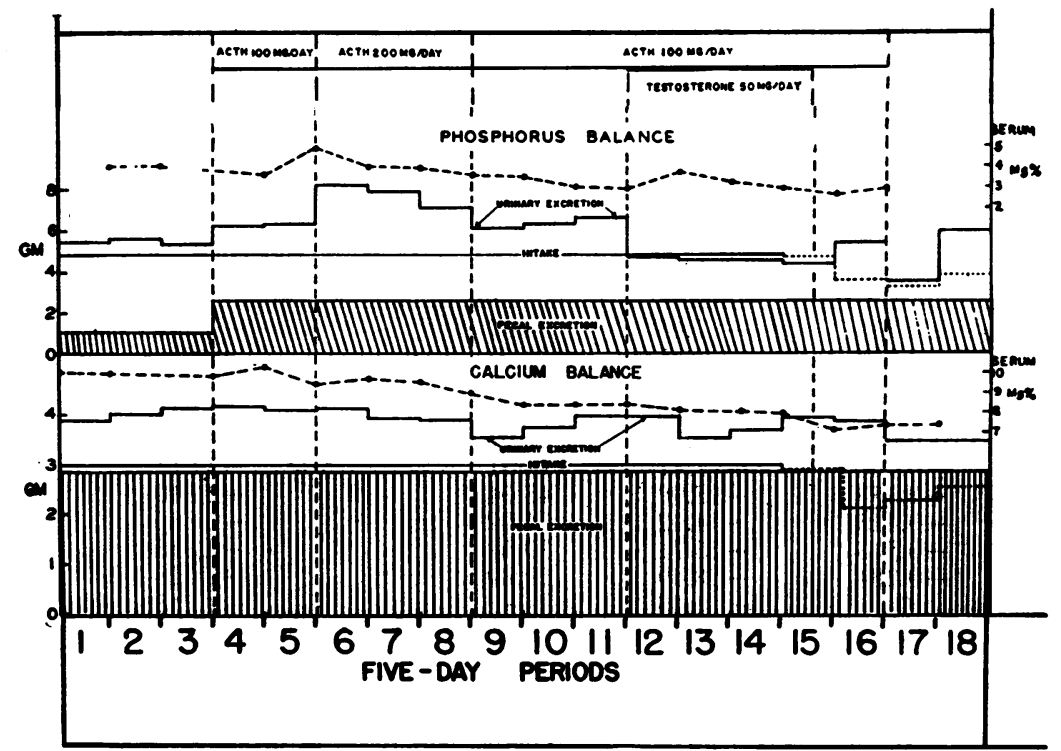

Fig. 10. Patient S. M. Effect of ACTh on Calcium and Phosphorus Balances and the Concentration of Calcium and Phosphorus in SERUM

For legend see Figure 1. 


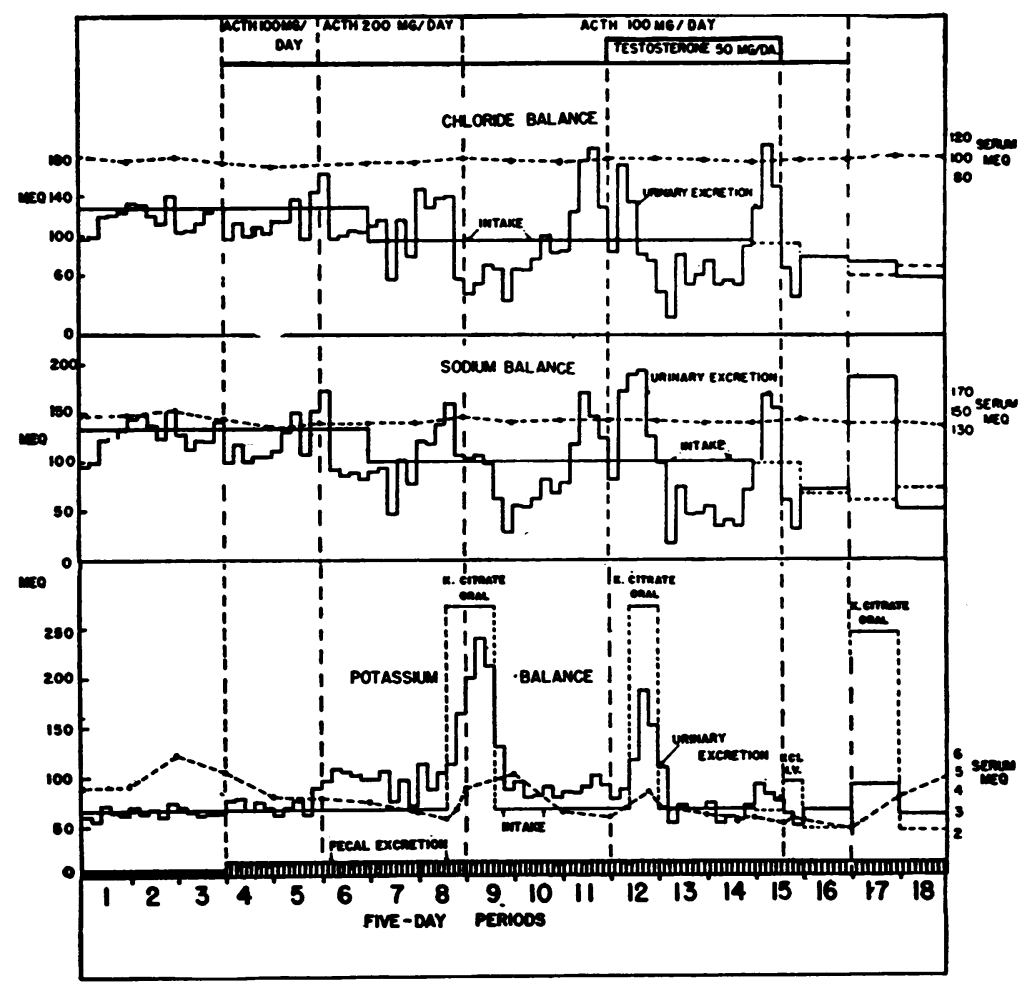

Fig. 11. Patient S. M. Effect of ACTH on Sodium Chloride and Potassium Balances

For legend see Figure 1.

by a period of nitrogen equilibrium. The response to ACTH at a dosage of $40 \mathrm{mg}$. per day intramuscularly was prompt. Urinary nitrogen in- creased markedly and the nitrogen balance became strongly negative (Table I). The patient continued to lose nitrogen in progressively increasing

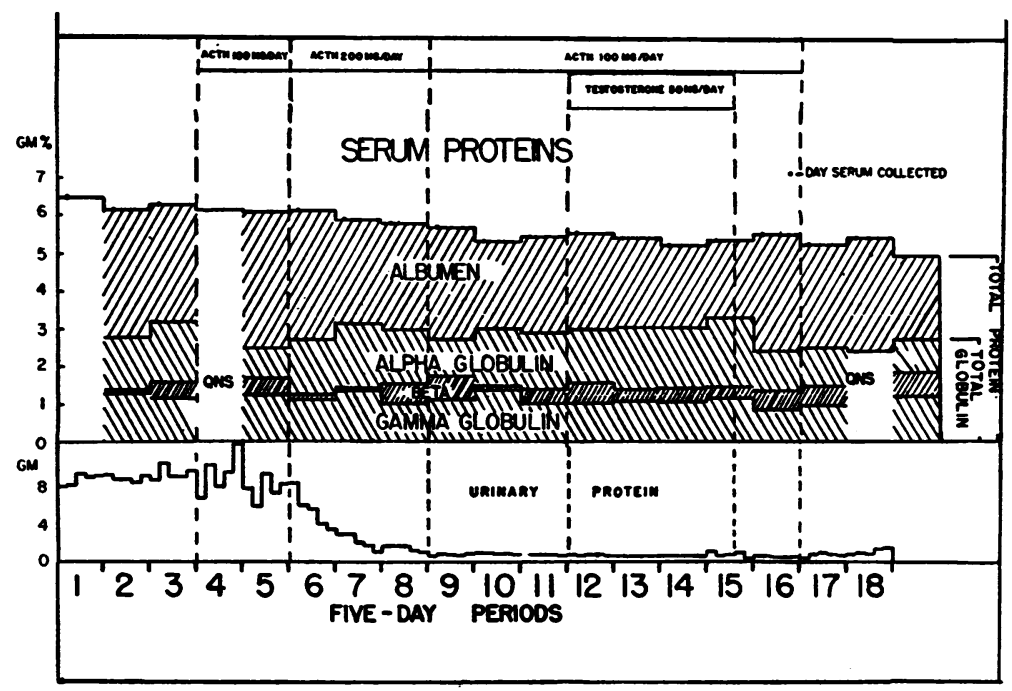

Fig. 12. Patient S. M. Effect of ACTH on Serum and Urinary Protein 


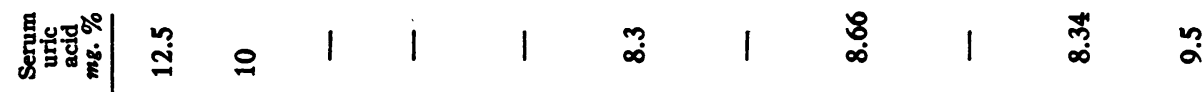

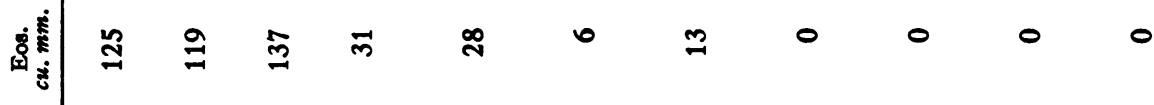

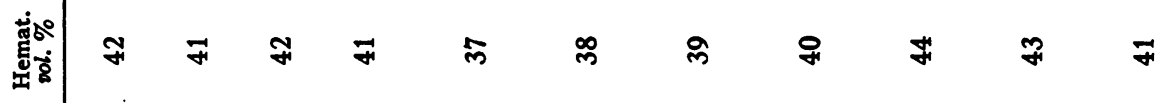

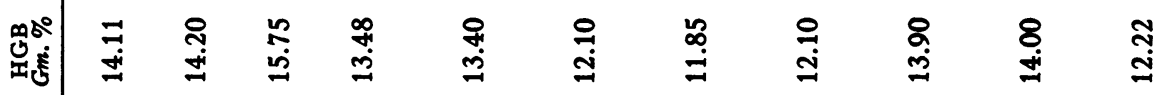

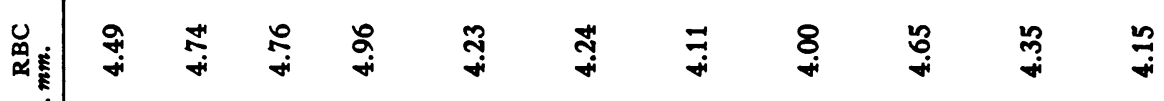

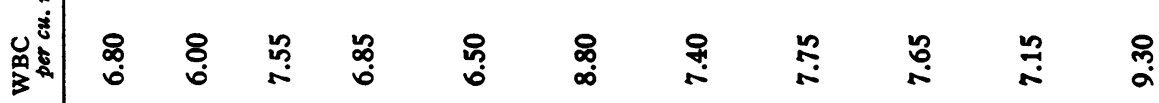

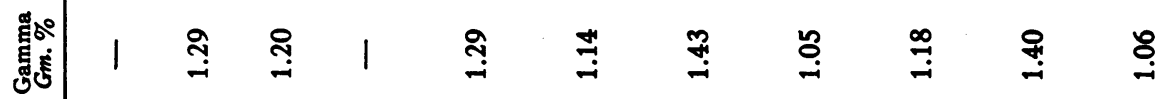

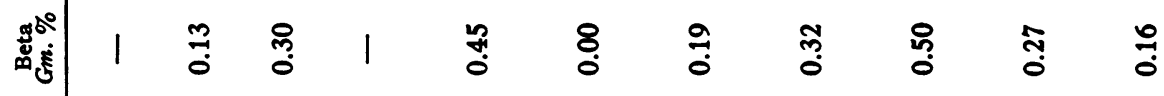

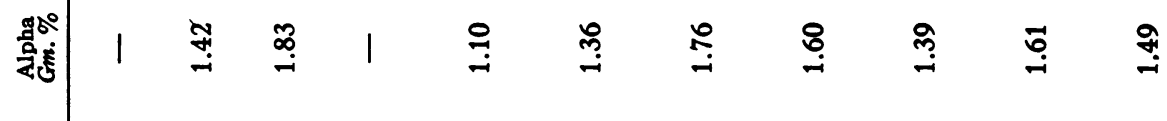

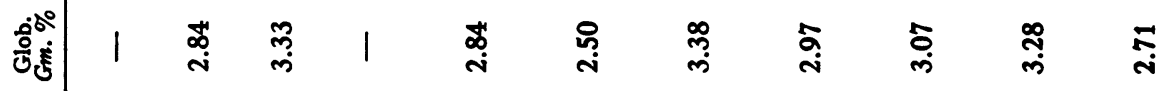

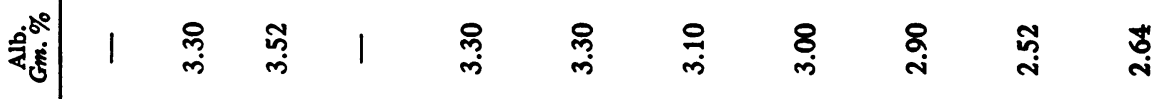

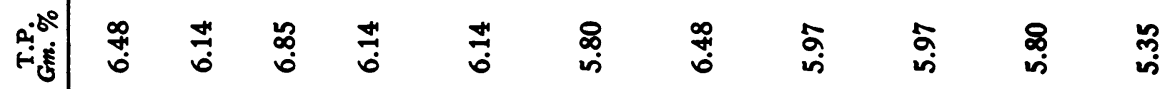

ठํํำ

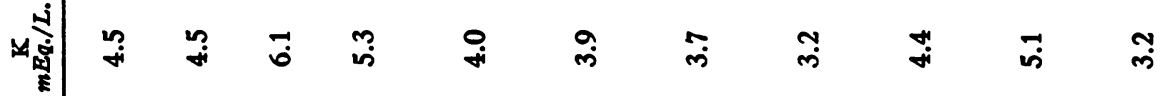

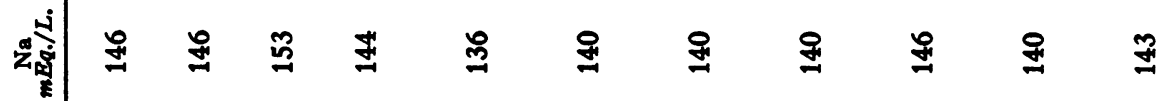

$1=71$ के

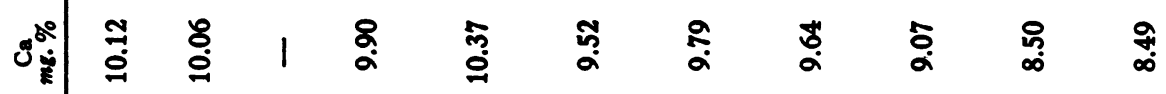

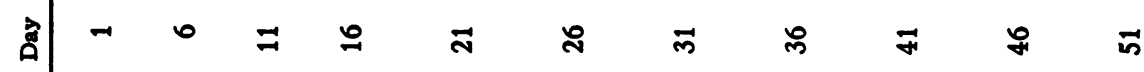

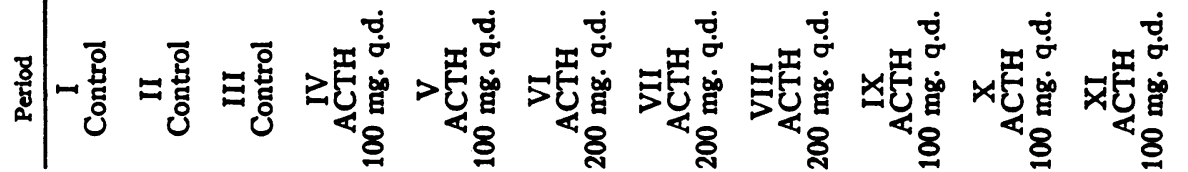


METABOLIC STUDY IN MULTIPLE MYELOMA DURING ACTH THERAPY

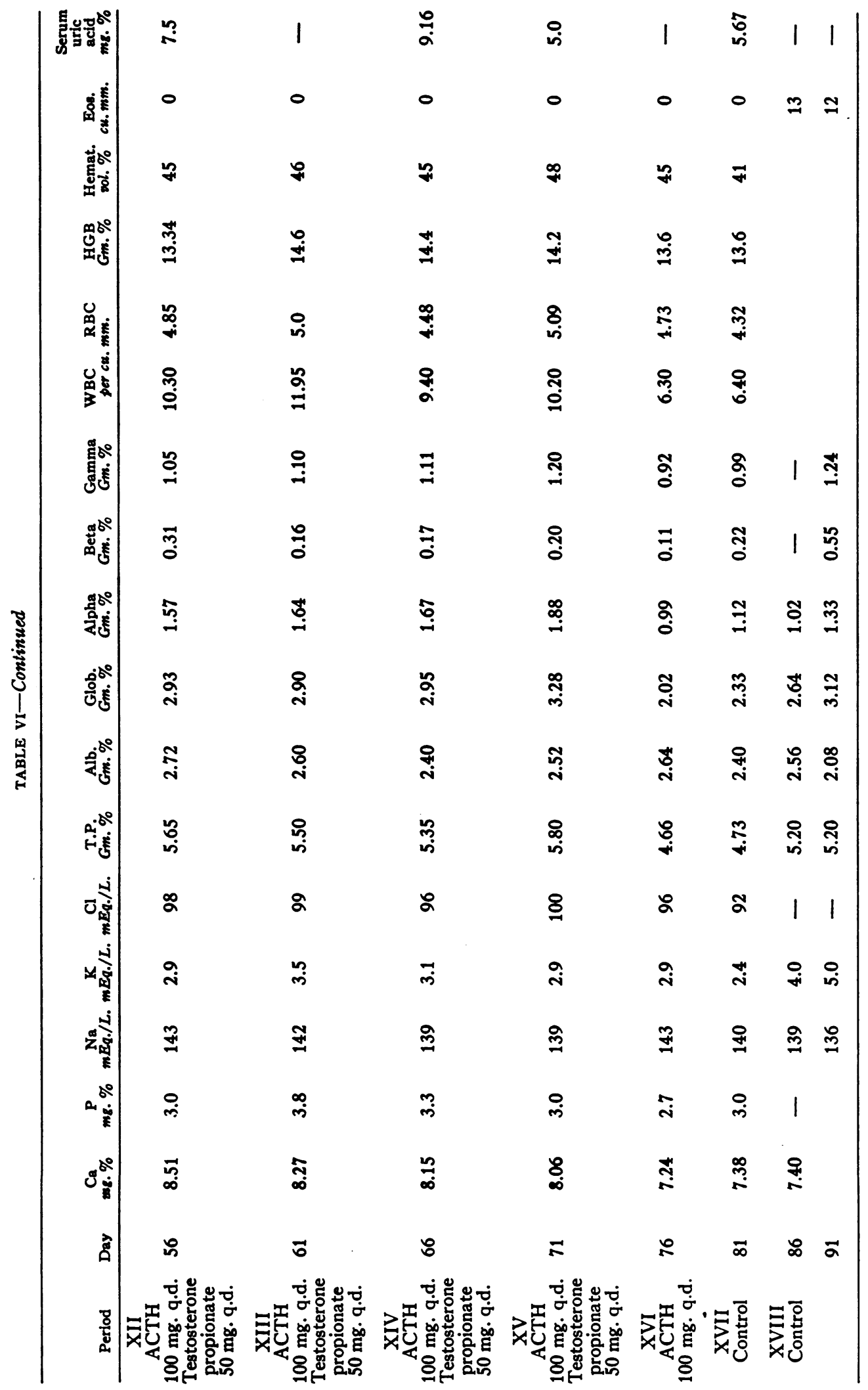




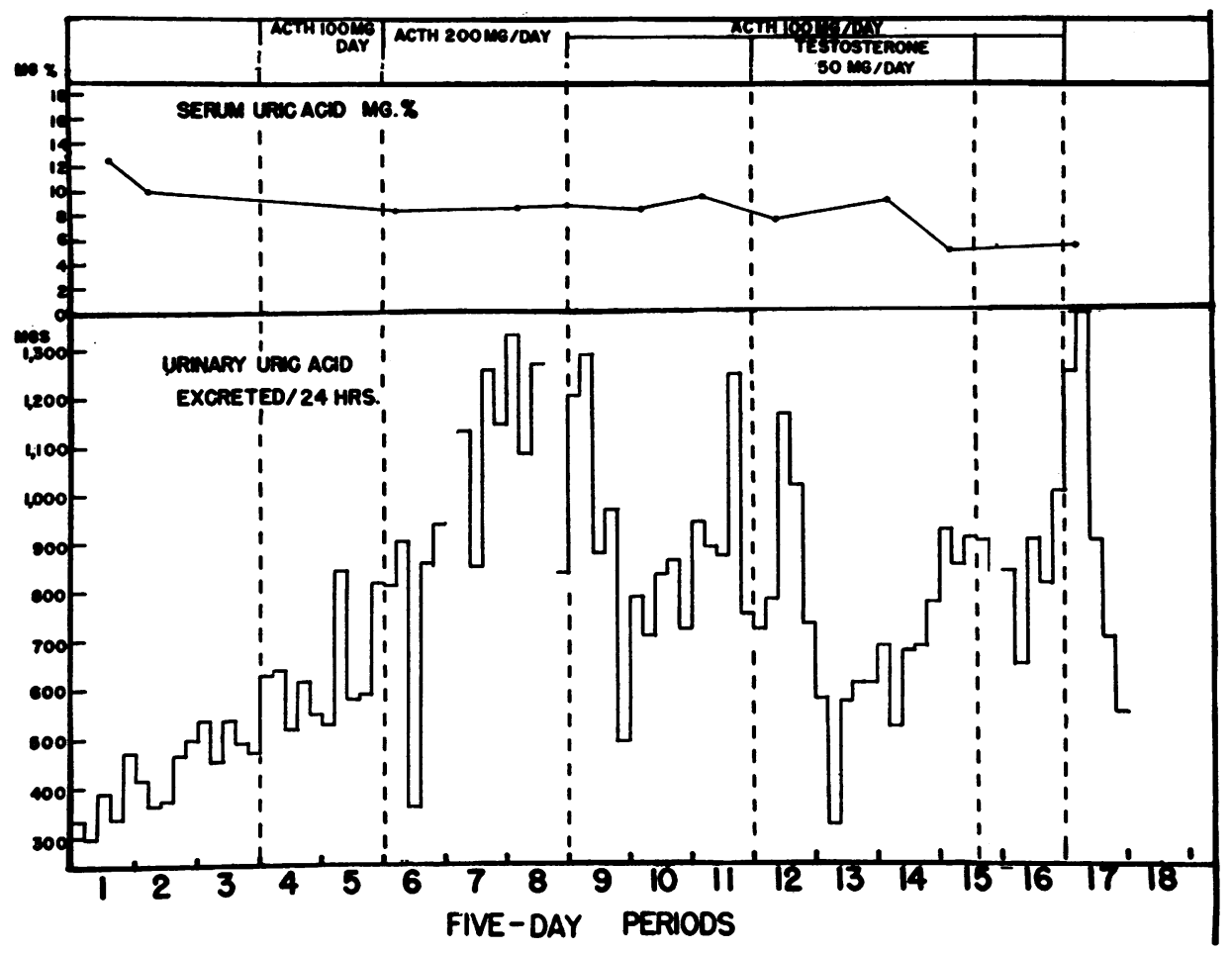

Fig. 13. Patient S. M. Effect of ACTh on Serum Uric Acid and Excretion of Uric ACID IN URINE

amounts for the next 15 days when the study had to be discontinued due to an acute intercurrent infection.

B. Calcium balance: The average calcium intake was $624 \mathrm{mg}$. per day with a calcium/phosphorus ratio of 0.6 . The calcium balance was consistently negative since the amount excreted in the stool was slightly in excess of the intake. (Figure 2 and Table I.) Urinary calcium averaged 50 to 60 mg. during control periods but increased considerably while the patient was receiving ACTH (Table III). Whether this increase should be attributed to ACTH or to the acute inflammatory process from which he ultimately succumbed is uncertain. There were no important changes in the concentration of serum calcium, and fecal excretion of calcium remained relatively constant.

C. Phosphorus balance: The administration of ACTH increased both the urinary and fecal excretion of phosphorus and the balance became strongly negative. (See Figure 1 and Table I.) The theoretical phosphorus balance and the nitrogen/phosphorus ratios have not been reported for this patient since the balance study was short and complicated in its terminal phases by an acute febrile illness.

D. Sodium, chloride, and potassium balances: Moderate losses of sodium unaccompanied by similar losses of chloride occurred in control periods. During the first period on ACTH both sodium and chloride were retained in large amounts (Figure 3 and Table I). Chloride continued to be retained in the second ACTH period although in much smaller amounts. "Escape" from the effect of the hormone occurred in the final period with release of large and approximately equivalent quantities of both elements. The potassium balance followed that of nitrogen rather closely and was strongly negative during administration of corticotropin. No significant changes in the concentration of serum electrolytes occurred.

E. Serum proteins: Prior to therapy with ACTH the concentration of serum protein averaged $12 \mathrm{Gm}$. per cent, of which $7.5 \mathrm{Gm}$. per cent precipitated as globulin at 18.5 per cent saturation with sodium sulphate (Figure 4). After ten days treatment with corticotropin, the globulins separating at $\mathbf{1 8 . 5}$ per cent saturation were reduced to 4 
Patient J. M.

A. Nitrogen balance: On admission the patient weighed $64.8 \mathrm{Kg}$. and was in slightly negative nitrogen balance, while ingesting a daily diet of 1,919 calories and $68.8 \mathrm{Gm}$. protein (Table IV). The loss of nitrogen increased slightly when he was given $40 \mathrm{mg}$. of ACTH a day intramuscularly. The daily dose of corticotropin was then increased to $80 \mathrm{mg}$. with a further moderate increase in the loss of nitrogen (Figure 5). The dose of ACTH was then reduced to the initial level of $40 \mathrm{mg}$. per day with gradual decrease in urinary nitrogen until equilibrium was established at the end of ten days. No further change in nitrogen balance was observed when hormone was discontinued.

B. Calcium balance: Calcium intake averaged $1200 \mathrm{mg}$. per day with a calcium/phosphorus ratio of 0.81 and hence conformed to currently accepted standards for optimum dietary requirements. Both the concentration of calcium in serum and the amount excreted in the urine decreased somewhat during ACTH administration (Figure 6 and Table III). Fecal calcium, on the other hand, increased moderately so that the net balance was negative both during the control periods and during periods of therapy (Figure 8). However, the loss of calcium was greater during the initial control periods than at any other time.

C. Phosphorus balance: Administration of ACTH in amounts of 40 and later $80 \mathrm{mg}$. per day was associated with a negative phosphorus balance (Figure 5 and Table IV). It was of some interest that the excretion of phosphorus in urine did not increase appreciably and that the loss of phosphorus was largely the result of a considerable increase in fecal phosphorus (Figure 8). Computation of the theoretical phosphorus balance and the nitrogen/ phosphorus ratios suggested that during periods of corticotropin therapy a tissue poor in phosphorus was being catabolized (Tables IV and V).

D. Serum proteins: The alpha globulin component of the serum proteins was markedly increased initially, averaging $3 \mathrm{Gm}$. per cent. There was a gradual decrease in this fraction during the course of ACTH administration to a final value of $2.0 \mathrm{Gm}$. per cent (Figure 7).

E. Urinary proteins: The urinary protein (Bence-Jones) decreased during therapy from an average control value of $17.7 \mathrm{Gm}$. in 24 hours to
4.4 Gm. in period IX. Thereafter, with a decrease in the dose of ACTH from 80 to $40 \mathrm{mg}$. per day there was a small and probably insignificant increase in urinary protein (Table II).

Patient S. M.

A. Nitrogen balance: The patient weighed 68.6 $\mathrm{Kg}$. at the outset of the balance program and ingested a diet providing approximately $1,930 \mathrm{cal}$ ories and $69 \mathrm{Gm}$. of protein a day. On this regimen he was essentially in nitrogen equilibrium during the first three control periods and during the first two ACTH periods when he received $100 \mathrm{mg}$. of hormone daily. However, upon increasing the dose to $200 \mathrm{mg}$. a day, a marked catabolic effect was observed, and this effect continued despite reduction in the dose from 200 to $100 \mathrm{mg}$. in periods IX, X, and XI. Administration of $50 \mathrm{mg}$. of testosterone proprionate daily (periods XII through XIV) gradually reversed the strongly negative nitrogen balance and brought about nitrogen equilibrium despite continuation of ACTH in amounts of 100 mg. (Figure 9 and Table VII).

B. Calcium balance: The average daily calcium intake was $590 \mathrm{mg}$. and the calcium/phosphorus ratio was approximately 0.6 . The amount of calcium intake and calcium/phosphorus ratio were somewhat suboptimal according to current concepts of calcium requirement (27). However, there is no reason to suppose that a normal subject ingesting a similar diet would have been in negative calcium balance. Nevertheless, the patient was in consistently negative calcium balance throughout control periods and periods of ACTH administration. Urinary calcium was reduced from an average daily control value of $223 \mathrm{mg}$. to $175 \mathrm{mg}$. during ACTH periods IX, $\mathrm{X}$, and XI (Table III). The concentration of serum calcium fell progressively from a control value of $10.1 \mathrm{mg}$. per cent to a low of $7.2 \mathrm{mg}$. per cent (Figure 10 and Table VI). The latter value was observed when the concentration of the serum proteins had fallen to 4.7 Gm. per cent and was quite possibly related to the hypoproteinemia. Fecal excretion of calcium remained relatively constant (Figure 8) .

C. Phosphorus balance: The administration of ACTH increased both the urinary and fecal excretion of phosphorus, and the balance became strongly negative (see Figures 9 and 10). As with patient J. M., the theoretical phosphorus balance 
was calculated according to the method of Reifenstein, Albright, and Wells (28) (See Tables V and VII). During the first three periods (Control) there was very little unaccountable phosphorus. In the next four ACTH periods, there were losses of phosphorus in excess of what one would predict from the nitrogen and calcium balances, suggesting catabolism of a phosphorus rich tissue. These were followed by four periods (VIII, IX, X, and $\mathrm{XI})$ when the theoretical phosphorus balance was more negative than the actual phosphorus balance and hence possibly indicated catabolism of tissue of low phosphorus content. The simultaneous administration of both testosterone propionate ( 50 mg. per day) and ACTH (100 mg. per day) led to phosphorus retention in spite of a continued negative calcium balance and nitrogen equilibrium (Periods XII through XV). Thus, it is apparent that under the experimental conditions the anabolic effect of testosterone was exhibited more strongly with respect to phosphorus than to nitrogen. Whether this points to resynthesis of myeloma tissue or has a different explanation cannot be determined from the information available.

When the concentration of potassium in the serum fell below $3 \mathrm{mEq}$. per liter during ACTH therapy, extra potassium as citrate was given on three separate occasions (see Figure 9). The urinary phosphorus decreased each time coincident with potassium administration. The ingestion of potassium did not alter the nitrogen balance which remained strongly negative and hence in this respect also did not parallel the phosphorus exchange.

D. Sodium, chloride, and potassium balances: The response to prolonged ACTH administration was variable and complicated as shown by the sodium and chloride balances (Figure 11 and Table VII). An initial strongly positive salt balance occurred in Period IV when the hormone was first given and was followed by a state approaching equilibrium in Period V. With the increase in ACTH dose to $200 \mathrm{mg}$. per day in Period VI, salt retention again became marked, only to be followed by salt loss in Period VIII. It seems probable that the negative balance in the latter period represented "escape" at least in part from the action of the hormone since the increase in urinary sodium and chloride preceded ingestion of supplementary potassium. Although administra- tion of potassium was continued into Period IX, a cycle of salt accumulation developed again which lasted through most of Period $\mathrm{X}$. The reverse phenomenon was noted in Periods XI and XII. Thus, the entire duration of ACTH and testosterone therapy seems to have been characterized by alternating cycles of salt retention and loss which may well be related to the transient shifts of water, sodium, and chloride into the extracellular space as described by Levitt and Bader (29). The final discontinuance of ACTH in Period XVII was dictated by a toxic psychosis and hypopotassemia for which potassium citrate was given for the third time in doses equivalent to $8 \mathrm{Gm}$. of potassium daily. As a result, more than $700 \mathrm{mEq}$. of potassium were retained and $600 \mathrm{mEq}$. of sodium were lost in five days. The effect on the chloride balance was comparatively minor and amounted to a negative balance of $73 \mathrm{mEq}$. As sodium and chloride loss and potassium retention are distinctive features of ACTH withdrawal, it is probable that the unusually large storage of potassium may have promoted a loss of cell sodium and, therefore, an exceptionally large sodium diuresis. The usual excretion of potassium in excess of intake was observed during administration of corticotropin (Figure 11). Extra potassium as citrate was given orally in Periods VIII, IX, XII, and XVII, and as chloride intravenously (Period XV) to combat hypopotassemia. Although potassium was retained during the time of administration of each supplement, the effect on the concentration in serum was fleeting.

E. Serum proteins: This patient was the only one of the three who had a relatively normal pattern of plasma proteins, both by electrophoresis and by the method of salt fractionation (see Table VI). At the outset of the balance study the gamma globulin components were slightly elevated. However, during prolonged administration of ACTH the concentrations of both albumin and globulin decreased progressively (Figure 12) and a moderate hypoproteinemia developed. Simple dilution was not considered to be a causal factor since the value of the packed erythrocytes remained essentially unchanged, and the body weight decreased.

F. Urinary proteins: There was a significant reduction in the excretion of Bence-Jones protein in the urine (Figure 12). An average of about 9 
Gm. of protein was recovered per day from the urine during control periods and there was little change after administering ACTH for ten days in daily doses of $100 \mathrm{mg}$. When the dose of ACTH was increased to $200 \mathrm{mg}$., the proteinuria decreased after eight days to approximately $2.0 \mathrm{Gm}$. per day, and by the fifteenth day from 0.7 to $0.8 \mathrm{Gm}$. per day, within which range it remained until the patient left the hospital two months later (Table II).

G. Uric acid: Quantitative determinations of the excretion of uric acid were made only in the case of S. M. (Figure 13). The control value averaged $497 \mathrm{mg}$. per day (Period III) just prior to administration of $\mathrm{ACTH}$, and increased to a maximum daily average of $1021 \mathrm{mg}$. in Period VIII. While there were marked fluctuations in the amounts eliminated during 24 hours, the highest rates of excretion coincided fairly well with the larger doses of adrenocorticotropin. The concentration of uric acid in the serum decreased progressively from $12.0 \mathrm{mg}$. per cent to $4 \mathrm{mg}$. per cent.

\section{DISCUSSION}

\section{Response to therapy}

It has been suggested that the variable response of different patients with multiple myeloma to chemotherapeutic (and hormonal) agents may point to different chemical mechanisms within the myeloma cells and that the diverse plasma protein patterns may be an expression of these cellular peculiarities (3). Although our patients revealed no uniform derangement in the plasma protein components, all responded similarly to adrenocorticotropin. One patient had considerable increase in the plasma protein fraction which "salted" out as gamma globulin. ${ }^{3}$ In another, the alpha globulin fraction was distinctly increased, and in a third the several components were essentially normal in distribution. Bence-Jones proteinuria, however, was a characteristic finding in each and was markedly decreased during therapy in two patients and slightly decreased in the third. The concentration of plasma protein fell also, with the most pronounced effect on the abnormal globu-

8 Salt fractionation was utilized to partition the various plasma protein components. Admittedly, errors are inherent in the method and the designation of globulins as alpha, beta, or gamma refers only to the fact that these proteins "salted" out as alpha, beta, or gamma fractions. lin fraction in the two patients who exhibited this deviation. The regression in Bence-Jones protein in the urine did not strictly parallel the decrease in plasma protein, but in one patient, S. M., appeared to be more closely related to the development of a strongly negative nitrogen balance. The failure of some investigators to observe changes in plasma protein or proteinuria in myeloma may indicate inadequate dosage or duration of application of the therapeutic agent rather than refractoriness of the disease. This seems to be born out in the response of J. M. and S. M. who showed little effect of treatment with small doses of adrenocorticotropin and definite effects when the dosage was substantially increased.

\section{Calcium and phosphorus exchanges}

Skeletal decalcification in multiple myeloma is commonly observed as a late manifestation of the disorder and appears in part in the form of discrete osteolytic lesions and in part as generalized osteoporosis. The discrete areas of decalcification are produced by nests of tumor cells which cause reabsorption of the surrounding bone salts. The degree of calciuria may well be a reflection of this process $(30,31)$, and as such, an indication of the activity and extensiveness of the disease. When hypercalcemia occurs one may suspect, as suggested by Albright and Reifenstein (32), that the dissolution of bone salts is contributing calcium to the blood stream at a more rapid rate than it can be cleared by the kidneys. Since renal function is often seriously impaired in the terminal phases of myeloma, both hypercalcemia and hyperphosphatemia may occur without marked hypercalciuria. This appears to have been the situation in the case studied by Bulger, Dixon, and Barr (5). Another factor in our patients which may have contributed to the loss of calcium, was the presence of bone pain and pathological fractures in two individuals, J. M. and S. M. Both were relatively inactive and spent a considerable portion of their time in bed prior to therapy. Some of the decalcification in these men could well have been the result of the partial immobilization associated with their discomfort, since this in itself leads to negative calcium balance even in healthy subjects (33). None of the three had serious impairment of renal function nor hypercalcemia. The excretion 
of calcium in urine was greatest in J. M. (291 mg. per day) during his control periods when, because of a recent collapse of a vertebral body, he was obliged to remain practically immobile in bed. J. D., on the other hand, had little bone pain and was quite active during control observations. His urinary calcium was the lowest of the three and averaged $13 \mathrm{mg}$. per day prior to treatment. Although ACTH is considered to have a catabolic effect on bones (26) as well as other tissues, as evinced by production of negative balances under intensive therapy, it appeared to increase the rate of decalcification only in J. D. The other two patients who became more active due to euphoria, increased feeling of well-being, and later toxic psychosis associated with the administration of the hormone, showed a moderate decrease in calciuria. The possibility must not be overlooked that a recession in the activity of the tumor growth may have been a contributing factor also. In favor of this was the observation that Bence-Jones proteinuria was greatly lessened in both these men, much more so than in patient J. D. In one, S. M., there was a gradual fall in the level of serum calcium, but whether this represented a decrease in the activity of the osteolytic process or in the calcium binding by plasma protein, which also decreased in concentration, is not clear. Loss of calcium from the body appears to have been mainly by excretion in the urine, since fecal excretions were on the average nearly equal to intake. However, in J. M. the mean fecal calcium increased during the periods of ACTH therapy, while in S. M. it revealed only the usual period-to-period fluctuation.

In the case of phosphorus, ACTH not only increased the amount in the urine, but also that appearing in the stools. This was particularly noticeable in patient S. M. who about tripled his excretion of fecal phosphorus during the time the larger doses of hormone were given (Figure 8A and $\mathrm{B}$ ). Excessive amounts of calcium did not appear in the stools of this man so that the shift in partition of phosphorus from urine toward feces cannot be related to calcium. It is of some interest that the excretion of phosphorus in urine was sharply reduced during those days when a positive potassium balance was achieved by the ingestion of potassium citrate. The possibility that the decrease in urinary phosphorus resulted from alkalinization in- duced by potassium citrate must be considered. While it is generally conceded that acidosis increases the excretion of urinary phosphate, the observations of Pitts and Alexander (34) on the dog do not support the view that the converse is produced by alkalosis. It would seem that the phosphate buffer system is equally important, both in states of acidosis and alkalosis and that the availability of phosphorus might be the major factor determining its excretion. The interdependence of potassium and phosphorus in cellular metabolism may have required retention of the latter when potassium was entering cells. The catabolic effect on nitrogen excretion, however, was not abolished by potassium and in this respect differed from the action of potassium chloride in the rat, as reported by Whitney and Bennett (35).

The agitation and anxiety which had gradually developed on prolonged treatment of two patients with adrenocorticotropin and which was at first suspected to be associated with the hypopotassemia, seemed to be little influenced by potassium retention accompanying supplementation of the diet, and we were unable to confirm the temporary improvement in psychotic behavior reported (36) when potassium deficiency was relieved. It is true that the concentration of potassium in the serum increased each time the element was ingested in large doses, but there was no salutary effect on the patient's behavior. Possibly, more prolonged or more vigorous potassium therapy was indicated and in view of the observations of others (36) would seem to warrant further investigation.

Although one of our three patients has sustained a remission in the course of his disease, the authors wish to emphasize that no conclusion should be drawn as to the therapeutic benefit of ACTH in multiple myeloma.

\section{SUM MARY}

1. Three cases of multiple myeloma are reported in whom the effect of administration of ACTH was observed during hospitalization in the Metabolic Unit.

2. Decreases in the concentration of serum proteins were observed in all three patients during therapy. In two, the effect was mainly on the abnormal globulin, while in the third all components of the serum proteins decreased. Proteinuria also decreased and in one patient at least, the di- 
minished excretion of protein appeared to coincide with the development of a strongly negative nitrogen balance during administration of ACTH (Patient S. M.).

3. Negative phosphorus balances were noted during the course of treatment in all instances. However, the dose required to produce this effect varied considerably from individual to individual. In general, the phosphorus exchange was not remarkable except for marked decrease in urinary phosphorus which occurred in periods when supplementary potassium was administered because of potassium deficiency.

4. Calcium balances were consistently negative in the two subjects who excreted the larger quantities of calcium in the urine. Subject J. D. was in calcium equilibrium during the preliminary periods of observation, and the balance became negative only during ACTH administration. ACTH did not appear to increase calcium excretion in the other two patients. The serum calcium of one individual (S. M.) decreased in approximate proportions to the decrease in concentration of his serum proteins.

5. The ingestion of $200 \mathrm{mEq}$. per day of extra potassium relieved the hypopotassemia which was observed during the therapy of S. M. but did not relieve a concomitant mild toxic psychosis.

6. ACTH therapy was associated with a remission in one subject (S. M.) which has continued for more than two years, but since continued evidence of the myelomatous process is still present in the bone marrow, the disease cannot be considered cured.

\section{ACKNOWLEDGMENT}

The authors wish to acknowledge the editorial assistance of Mrs. Hans Jordan and her contribution in the translation of bibliographical material. They are also indebted to Mr. William J. McCandless, Mrs. Pauline Schatz, Mrs. Betty Yost, and Mrs. Frances Davis for technical assistance, and to Miss Sophie Bloom for the preparation of the manuscript.

\section{REFERENCES}

1. Adams, W. S., Bassett, S. H., Goldman, R., and Lawrence, J. S., The use of ACTH in multiple myeloma. Veterans Administration Conference on Cortisone Research, A symposium, August 1950, Washington, D. C., Merck \& Co., 1951, 69.

2. Pearsan, O. H., Eliel, L. P., and Talbott, T. R., Jr., The use of ACTH and cortisone in neoplastic dis- ease. Bull. New York Acad. Med., 2nd Series, 1950, 26, 235.

3. Engle, R. L., Jr., and Barr, D. P., Multiple myeloma treated with ACTH. Proc. of the Second Clin. ACTH Conf., J. R. Mote, ed., N. Y., Phila., Blakiston Press, 1951, 2, 209; Bethell, F. H., Discussion of Engle, R. L., and Barr, D. P., Multiple myeloma treated with ACTH. Ibid., 1951, 2, 216.

4. Thorn, G. W., Forsham, P. H., Frawley, T. F., Hill, S. R., Jr., Roche, M., Staehelin, D., and Wilson, D. L., The clinical usefulness of ACTH and cortisone. New England J. Med., 1950, 242, 824.

5. Bulger, H. A., Dixon, H. H., and Barr, D. P., The functional pathology of hyperparathyroidism. J. Clin. Invest., 1930, 9, 143.

6. Blatherwick, N. R., Calcium and Bence-Jones protein excretion in multiple myeloma. Am. J. M. Sc., 1916, 151, 432.

7. Seegelken, C., Ueber multiples Myelom und Stoffwechseluntersuchungen bei demselben. Deutsches Arch. f. Klin. Med., 1897, 58, 276.

8. Williams, O. T., Some observations on the nature of the Bence-Jones' protein. Biochem. J., 1911, 5, 225.

9. Hopkins, F. G., and Savory, H., A study of BenceJones protein, and of the metabolism in three cases of Bence-Jones proteinuria. J. Physiol., 1911, 42, 189.

10. Allard, E., and Weber, S., Ueber die Beziehungen der Bence-Jonesschen Albumosurie zum Eiweissstoffwechsel. Deutsche Med. Wochenschrift, 1906, 32, 1251.

11. Currie, R. A., Case of Bence-Jones proteinuria, with note on urinary excretion of mineral elements. Glasgow M. J., 1927, 107, 31.

12. Washburn, M. L., and Shear, M. J., Composition of bone; XIII. Direct gravimetric determination of $\mathrm{Ca}, \mathrm{Mg}$, and PO. J. Biol. Chem., 1932, 99, 21.

13. Van Slyke, D. D., and Sendroy, J., Jr., Gasometric determination of oxalic acid and calcium, and its application to serum analyses. J. Biol. Chem., 1929, 84, 217.

14. Fiske, C. H., and Subbarow, Y., The colorimetric determination of phosphorus. J. Biol. Chem., 1925, 66, 375.

15. Hiller, A., Plazin, J., and Van Slyke, D. D., A study of conditions for Kjeldahl determination of nitrogen in proteins. Description of methods with mercury as catalyst, and titrimetric and gasometric measurements of the ammonia formed. J. Biol. Chem., 1948, 176, 1401.

16. Eisenman, A. J., A note on the Van Slyke method for the determination of chloride in blood and tissue. J. Biol. Chem., 1929, 82, 411.

17. Harvey, S. C., The quantitative determination of the chlorides in the urine. Arch. Int. Med., 1910, 6, 12.

18. Van Slyke, D. D., The determination of chlorides in blood and tissues. J. Biol. Chem., 1923, 58, 523. 
19. Howe, P. E., The determination of proteins in blood -a micro method. J. Biol. Chem., 1921, 49, 109.

20. Majoor, C. L. H., The possibility of detecting individual proteins in blood serum by differentiation of solubility curves in concentrated sodium sulfate solutions. II. Comparison of solubility curves with results of electrophoresis experiments. J. Biol. Chem., 1947, 169, 583.

21. Hiller, A., Greif, R. L., and Beckman, W. W., Determination of protein in urine by the biuret method. J. Biol. Chem., 1948, 176, 1421.

22. Kalckar, H. M., Differential spectrophotometry, of purine compounds by means of specific enzymes. I. Determination of hydroxypurine compounds. J. Biol. Chem., 1947, 167, 429.

23. Praetorius, E., An enzymatic method for the determination of uric acid by ultraviolet spectrophotometry. Scandinav. J. Clin. \& Lab. Invest., 1949, 1, 222.

24. Lüdin, H., Zur Kenntnis der Eiweissstoffwechselstörung beim Plasmocytom. Schweiz. med. Wchnschr., 1947, 77, 190.

25. Wuhrmann, F., Wunderly, C., and Wiedemann, E., Ueber das alpha-globulin-plasmocytom. Schweiz, med. Wchnschr., 1948, 78, 180.

26. Sprague, R. G., Power, M. H., Mason, H. L., Albert, A., Mathieson, D. R., Hench, P. S., Kendall, E. C., Slocumb, C. H., and Polley, H. F., Observations on the physiologic effects of cortisone and ACTH in man. Arch. Int. Med., 1950, 85, 199.

27. Hawley, E. E., and Maurer-Mast, E. E., The fundamentals of nutrition, Springfield, Ill., Charles C Thomas, 1940, Chapter IV, The normal diet, p. 51.

28. Reifenstein, E. C., Jr., Albright, F., and Wells, S. L., The accumulation, interpretation, and presentation of data pertaining to metabolic balances, notably those of calcium, phosphorus and nitrogen. J. Clin. Endocrinol., 1945, 5, 367.

29. Levitt, M. F., and Bader, M. E., Effect of cortisone and $\mathrm{ACTH}$ on fluid and electrolyte distribution in man. Am. J. Med., 1951, 11, 715.

30. Laszlo, D., Schulman, C. A., Bellin, J., Gottesman, E. D., and Schilling, A., Mineral and protein metabolism in osteolytic metastases. J. A. M. A., 1952, 148, 1027.

31. Schilling, A., and Laszlo, D., Rate of urinary calcium excretion following its intravenous administration as an indicator of bone metabolism. Proc. Soc. Exper. Biol. \& Med., 1951, 78, 286.

32. Albright, F., and Reifenstein, E. C., Jr., The parathyroid glands and metabolic bone diseases. Selected Studies. Baltimore, Williams \& Wilkins Co., 1948.

33. Whedon, G. D., Deitrick, J. E., and Shorr, E., Modification of the effects of immobilization upon metabolic and physiologic functions of normal men by the use of an oscillating bed. Am. J. Med., 1949, $6,684$.

34. Pitts, R. F., and Alexander, R. S., The renal reabsorptive mechanism for inorganic phosphate in normal and acidotic dogs. Am. J. Physiol., 1944, 142, 648.

35. Whitney, J. E., and Bennett, L. L., Inhibition of the catabolic effect of adrenocorticotropic hormone (ACTH) in rats by a diet high in potassium chloride. Endocrinol., 1952, 50, 657.

36. Ransohoff, W., Brust, A. A., Reiser, M. F., Mirsky, I. A., and Ferris, E. B., The effect of sodium and potassium on the metabolic and physiologic responses to ACTH. Proceedings of the Second Clin. ACTH Confer., J. R. Mote; N. Y., Phila., Blakiston Co., 1951, 1, 160.

\section{SPECIAL NOTICE TO SUBSCRIBERS}

Post Offices will no longer forward the Journal when you move.

Please notify The Journal of Clinical Investigation, Business Office, 622 West 168th Street, New York 32, N. Y. at once when you have a change of address, and do not omit the zone number if there is one. 